\title{
The Global ELT coursebook: A case of Cinderella's slipper?
}

\author{
Freda Mishan \\ University of Limerick, Ireland \\ Email: freda.mishan@ul.ie
}

\section{Introduction}

English language teaching (ELT) publishing as we know it today has a long and lucrative history, dating, according to Rix (2008), from the Longman publication of Michael West's New Method Readers in 1926, to the present day, where annual turnover runs to around US\$194 billion (Jordan \& Gray, 2019). Some of the sector's best-sellers, such as Oxford University Press's Headway series (Soars \& Soars), have sold over 70 million copies (Ożóg, 2018) with OUP's English File (Latham-Koenig, Oxenden, \& Lambert) selling over a million copies in China alone. Generally speaking, it is taken for granted that commercial publications in the educational sector are based on sound, accepted pedagogical principles. Early language teaching publications (from the 1950s onwards) naturally reflected practices that were thought to promote language learning at that time - such as repetition, drills and sentence-level grammar exercises. As our understanding of language learning developed, this Structural approach gave way to a Communicative one, reflecting the 1970s preoccupation with the importance of communicative competence, influenced by theorists such as Hymes (e.g. 1972) and Halliday (e.g. 1975). This approach remains the predominant one (in the West at least) 50 years later. It represents, remarkably perhaps, the last time that applied linguistics substantially influenced a language teaching approach, or at least, one that had such global reach and enduring influence. Since then, findings from the fields of applied linguistics and second language (L2) acquisition, which should have fed into language learning approaches and hence language coursebooks, have been slow to do so in any systematic or significant way. Where they have, the way in which language learning theory 'translates' into pedagogy in the coursebook and thence classroom, can be questionable. In parallel with this is the problem of the socio-cultural standpoint of teaching materials of an international language such as English, issuing from a particular geographic heartland, viz. England. As with applied linguistics and L2 acquisition research, developments in sociolinguistic, socio-cultural and socio-political theory have been realised in language teaching coursebooks only as a rather superficial multi-cultural gloss. The advent of 'global' coursebooks conceived in the 1990s, with multiple iterations, attempting to capture international appeal, still has not resolved the conundrum that language - and hence language teaching materials, that is, the combination of content and pedagogy - constitute cultural artefacts, imbued with cultural values and ideologies. All in all, as Timmis, Mukundan, and Alkhaldi laconically observe: 'for such commonplace objects, [coursebooks] have aroused a surprising degree of controversy' (2009, p. 11). These then, are the chief areas of contention that I will develop in this article. Opposing these issues, it will be acknowledged that coursebooks remain the default language learning resource, and that teachers and learners world-wide need, want and value them as ready-made language teaching materials.

A quick caveat here. In line with the importance I have attached to context throughout the debate offered in this article I need to declare my own context and experience, which is my circa 40 years of working with UK-published coursebooks. So, my critique is based on these - even though it may apply to others. 


\section{Why coursebooks?}

Geo-political and sociological forces, including communications technology, have seen the English language spread to the extent that it is spoken as a first and second language, an international language and a lingua franca by around 2.3 billion people in the world (Crystal, 2019, p. 115). Additionally, the number of people actively learning English is around 1.85 billion, one in four people world-wide, according to Mayor (2016). The ELT industry has not only thrived in this environment but arguably created a market dependency. Packaging ELT materials as attractive, glossy coursebooks, together with support materials, teachers' books, CD-ROMs, DVDs, companion websites, Apps and so on, has set up a perception, among learners as well as teachers, of what constitutes 'proper' learning materials; they offer 'face-validity', in other words. The use of published coursebooks is largely the norm in today's language classroom, indeed they have remained as much 'the visible heart' of many ELT programmes as when Sheldon first made that observation over 30 years ago (1988, p. 237). Of the (surprisingly scarce) data available regarding coursebook use, general indications are that the majority of teachers - up to 92\% according to Tomlinson's 2010 survey - 'regularly' use a coursebook, with around 65\% 'always or frequently' using one (British Council survey, 2008).

Teachers, especially those who are new to the profession or have a heavy workload, or both, are happy to be able to avail themselves of ready-made materials from a trustworthy source (i.e. an international publisher). Because in language coursebooks 'the medium is the message', they exert a far stronger influence than do textbooks in other school subjects (Appel, 2011), effectively dictating the syllabus. This 'ready-made' syllabus provides learning objectives in the form of 'covering' the book with, in some contexts, end-of-course exams testing it. More fundamentally and more importantly, especially for novice teachers, coursebooks incorporate teaching methodology, with inbuilt classroom implementation techniques and formats; 'Most teachers and students [...] welcome published materials and can gain security, system and support from them' (Tomlinson \& Masuhara, 2018, p. 29). From the point of view of school administration, in what are frequently commercial institutions, putting the coursebook at the centre of the language programme streamlines it, avoiding the need to develop a syllabus and materials, standardising instruction, and, most crucially, saving time and money. The reliance of the ELT profession on these conveniently packaged materials is thus unquestionable.

What is apparent from the above, is that the arguments in favour of coursebooks are largely practical. McGrath's list of 'why coursebooks are so popular' (2013, p. 5), for example, runs to four pages of exclusively practical reasons. This is in contrast to the gamut of objections to coursebooks which are based on anything from ideological, socio-cultural, socio-political to pedagogical grounds, as will be developed below. There is significantly less literature written in support of the coursebook too, suggesting that it is left to speak for itself in a way.

Learners, for their part, tend to have traditional attitudes to learning and to the textbook that they feel encapsulates 'learnable' knowledge; as one learner expressed it in a study by Shawer, Gilmore, and Banks-Joseph, 2008, p. 19; 'the textbook is essential for knowledge we need to learn'. Students in the study reported in Hutchinson and Torres, 1994, viewed the textbook as a "framework" or "guide" that helps them to organize their learning', enabling them to learn 'better, faster, clearer (sic), easier (sic), more' (Hutchinson \& Torres, 1994, p. 318). Going further, a famous study by McGrath revealed that learners perceived their coursebooks as everything from a 'map' to a 'Bible' (McGrath, 2006, p. 176). These attitudes are understandable, particularly in non-English-speaking contexts, where the coursebook, as well as the teacher who mediates it, are the main (pedagogical) links to an English-speaking world; coursebooks are 'revered in many classrooms as the ultimate authority' (Tomlinson \& Masuhara, 2018, p. 41). It is striking though, as noted in Harwood (2014) and McGrath (2013), how little research there is on learner consumption and perception of coursebooks, and tellingly, most of the research emanates from the coursebook-sceptic camp, thus offering a somewhat skewed portrayal of what learners really like or want.

This gap is being addressed in some measure by research from a new group MUSE (materials in use international). Indeed, research on How coursebooks are used drills down more accurately into the 
data on the level of coursebook reliance (see above). All coursebook use involves a degree of mediation and thus inevitable variation. This accepted, there has been some research on the extent to which teachers adapt materials. Bolster $(2014,2015)$, for instance, in her study with 18 experienced teachers using an English for academic purposes (EAP) textbook, showed that no teacher 'wholly used the material as it was presented in the textbook' and that 'every exercise was adapted by some teachers (Bolster, 2015, p. 20). This meant a spread of ' $25 \%$ to $100 \%$ of changes made [...] to the published material, with an average percentage of adaptation of 64.5' (p. 20). This level of coursebook adaptation suggests that a 'critically selective and creative approach' whereby 'we take from a coursebook what is useful, shape it to learners' needs and supplement it' (McGrath, 2016, p. 16) is taken by most teachers. Adaptation, therefore, offers a pathway towards coursebook palatability for those opposed to them.

Adaptation has also been formalised as coursebooks with 'versioned' editions for specific contexts. Examples include a Polish version of face2face (Tims, Redstone, \& Cunningham, 2005) and a Middle-Eastern version of Challenges 3 (Williams, Mugglestone, \& Fricker, 2007). However, this of course brings us full circle back to the dictates of the international ELT publisher. In fact, one user of Challenges 3 found it disappointingly similar in content to any global coursebook (Benjamin, 2015). Versioned coursebooks from the major ELT publishers are in the minority in any case, with nationally or regionally-produced coursebooks being more common. These have been developed in many situations world-wide, often independently, as, for example, Algeria's middle school English language coursebooks On the Move (Arab, 2006) and series Spotlight on English (Merazga, 2003; Merazga, Achour, Ameziane \& Bouhaduba, 2004; Arab, Riche, Ameziane, Khouas \& Louadj, 2005). Others are developed in collaboration with Ministries of Education, as well as in collaboration with international publishers and/or writers. English for Life 1 (Tomlinson, Hill, \& Masuhara, 2000), for instance, was developed in collaboration with the Ministry of Education in Singapore. Primary English (Methold, 2000) was a Chinese/McGraw Hill collaboration (see Ping, 2018) and Go For It used in Chinese secondary schools, was written by David Nunan in collaboration with two Chinese authors and published by a Chinese publisher (as described in Zheng \& Zhou, 2016).

Another argument in favour of coursebooks is - what would REPLACE coursebooks? The most radical answer is 'nothing' - boycott it in the manner of the Dogme ELT extremists (led by Thornbury e.g. 2000) in favour of a return to the grass roots of the language classroom: the teacher and the learners. The Dogme 'philosophy' has evolved over the years but in essence refers to teaching that is 'materials light', instead being 'conversation driven' and focusing on 'emergent language' (Meddings \& Thornbury, 2009, p. 8). Thornbury seems to have conceded that in practice, rather than an overall approach, it is more likely to appear as 'Dogme moments' (Thornbury, 2017, p. 82); learning opportunities that alter the direction of the planned lesson. In an earlier work (Mishan, 2005), I made the argument for what are termed 'authentic materials', that is, materials not designed for language learning but overlaid with a pedagogical framework, at a time when this practice was burgeoning due mainly to the opening up of the Web - giving access to untold materials riches. Tomlinson's 'textdriven' approach (put forward in, for example, his 1998 publication with many other iterations) likewise used 'engaging' and often authentic (e.g. literary) texts to generate a 'retrospective' syllabus (emerging from, rather than imposed on, the learning materials). However, designing tailor-made learning/ teaching materials based on such, demands time, experience, confidence and creativity as well as facilities for printing and photocopying. A less taxing compromise, and probably the most commonly used (despite copyright law!) is for teachers to select, cut and paste from various coursebooks to create their own materials and possibly, their whole 'syllabus' - in essence, an extended form of adaptation. Published resource books or packs represent a useful half-way house but require selecting and adapting to the teaching context, as well as, often, the same practical preparation as with authentic materials (duplicating classroom handouts, etc.). The latest permutation of this genre are the exceptional publications from the British Council that foster a more global and social responsibility, notably Integrating global issues in the creative English language classroom: With reference to United Nations sustainable development goals (Maley \& Peachy, 2017). Most resource books, like versioned ones, come under the auspices of major Anglo-centric publishing houses, so might be viewed with the 
same scepticism as the coursebook itself. So let us now put the coursebook in the dock, so to speak, to try to understand which aspects have drawn such criticism from its opponents over the years.

\section{The coursebook under fire}

\subsection{Commercial success}

The ELT publishing industry has been controversial from fairly early on in its history. Tomlinson and Masuhara (2018) date publications that started to critique the coursebook from about the mid-1980s. At the root of much of it was the concessions that coursebooks had to make for commercial reasons (see, for example, Bell \& Gower (2011), discussed below), and the problems with this form the basis for many of the arguments I make in this article. A much-cited paper was representative of these early objections, railing against the triumph of commercial over pedagogical considerations:

There may be a closed circle at work here, wherein textbooks merely grow from and imitate other textbooks and do not admit the winds of change from research, methodological experimentation, or classroom feedback.

(Sheldon, 1988, p. 239).

Due, one would surmise, to their massive commercial success - total sales among the top four ELT publishers surpassed $£ 1$ billion in 2011 (Hadley, 2014) - coursebook formats have continued to replicate each other in a self-perpetuating 'washback effect' whereby new coursebooks are based on previous commercially successful models. This has made for a coursebook structure and 'look and feel' that have remained basically unchanged across the major ELT publishing houses (such as Oxford University Press, Cambridge University Press, Pearson Longman) for well over 25 years - not to mention their influence on coursebooks world-wide. What is most worrying about this is why, in what is an educational sector, commercially successful models are considered paradigms to be emulated - this would hardly be the case in other areas, such as popular fiction: 'best-sellers' do not tend to be lauded for their literary quality. A case in point is that the so-called 'global' coursebook has become a recognised international brand, an 'all-singing, all-dancing, glitzy (expensive) multimedia package' (Bell \& Gower, 2011, p. 137) with lucrative global sales ensuring high production quality. That this unquestionably compromises pedagogy is admitted by authors themselves; Bell and Gower's seminal chapter, originally published in 1998, is entitled 'Writing course materials for the world: A great compromise'. Here, they pinpoint the main problem in designing such coursebooks. They are destined for the international market but they emanate from a specific native-speaker situation, meaning that the materials, topics and teaching approaches can never be a fit for so many diverse end-users. Hence, we have the coursebook as the 'Cinderella's slipper' of the title of this article; really only a fit for one context, not the 'one size fits all' it purports to be.

\subsection{Culture in the ELT coursebook}

To be magnanimous, it could be said that much is asked of the humble ELT coursebook. The nature of teaching language is that it encapsulates the language's culture, making any language textbook a de facto cultural artefact. But the English language straddles cultures world-wide in vastly different contexts of use. These range from a 'native language', in so-called 'Inner Circle' countries (Kachru, 1985) Britain, Ireland, Australia, New Zealand and the USA, for instance - to use as a second language in over 50 'Outer Circle' territories such as Singapore, India and Malawi (Crystal, 2019, p. 113), the loci of what is referred to as World Englishes. Finally, there is the use of English as the international lingua franca by more than a billion English speakers in around 140 countries (Crystal, 2019, pp. 116-117). Its use and status in the world is thus diverse and ever-shifting; the total number of English speakers in the world has increased by $30 \%$ over the last 20 years, according to Crystal, to over 2.3 billion (2019, 
p. 115) (as noted above). Positioning a language teaching coursebook in such a vast and shifting landscape is a big ask indeed.

So how, in all this, has coursebook publishing risen to the challenge? The industry needed to respond to the changing position of English in the world, as well as to harsh criticisms of the global ELT coursebook from socio-political theorists and others, of its failure to do so. During the 1990s, there crept in, in certain academic circles at least, a sinister perception of the industry as constituting a form of neo-imperialism, in which geo-political colonisation was replaced with a linguistic and hence embedded cultural one. This view has been argued comprehensively by theorists such as Phillipson (1992), Pennycook (1994) and Canagarajah (e.g. 1999). One tenet of these arguments was that the growth of English was an intrinsic part of a general economic 'globalisation'. This further enhanced its global status and, perhaps buoyed by the government-funded British Council, perpetuated that legacy of the British Empire, linguistic hegemony - effectively making the ELT industry a co-conspirator: 'ELT is not a neutral endeavour but a cultural and political practice which has to be understood with regard to global and local power relations' (Ping, 2018, p. 178).

The extent to which this is in fact a deliberate, socio-political 'covert agenda' or merely an unavoidable factor of language pedagogy is a matter of much debate in the literature. Early critics were not long to expose the 'hidden curriculum' in language teaching: 'A curriculum (and teaching materials form part of this) cannot be neutral because it has to reflect a view of social order and express a value system, implicitly or explicitly' (Cunningsworth, 1995, p. 90). Resentment at being sold an ideological package along with a language learning coursebook permeates research from international writers:

Language in a textbook is not simply a linguistic system but contains and expresses aspects of culture - the same agenda, but with a cultural focus, may be pursued in ELT materials. It is important to investigate its realisation in ELT textbooks as there is otherwise a risk that textbook users may treat embedded cultural aspects and values as something to be acquired as part of successful TL (target language) learning.

(Tajeddin \& Teimournezhad, 2015, p. 183)

At one level, this points to the importance of critical treatment of coursebook materials by its users. More fundamentally though, this type of perception highlights the conundrum of the global coursebook at the heart of this article; namely, how to present language essential for attaining L2 competence within an acceptable cultural frame of reference.

In the late 1990s, the industry had attempted to respond to all this with the multi-million-pound revamp known as the 'global coursebook'. These were attractive multi-component packages destined for English teaching contexts world-wide. The coursebook content was varied and colourful; pages were given a webpage-like format with information presented in blocks or 'windows', to appeal to the digital generation. An effort was made to avoid an essentialist view of culture; texts and photographs were culled from around the globe, far from the red post boxes and black taxi cabs of their predecessors (although not quite ready, it seems, to divest themselves of the British Royal Family who still feature in even the latest editions of English File (Latham-Koenig, Oxenden, \& Lambert, 2019) and Headway (Soars \& Soars, 2019)). They studiously avoided topics that some of their end-users might find provocative or culturally inappropriate: politics, religion, sex, narcotics - even alcohol and pork were 'no-nos' (the tongue-in-cheek acronym PARSNIP was coined by critics of this practice). All this did nothing to address the underlying cultural conundrum. On the contrary, 'blocked from portraying anything but a particular version of reality by risk-averse publishers' (McCarthy, 2020, p. 10), the PARSNIP-compliant subject matter typically presented in global coursebooks: jobs, technology, leisure, travel, the environment, entertainment (that these are all stubbornly middle-class concerns is developed below) epitomise 'Western' values and traits such as ambition, individualism, assertiveness and consumerism/materialism. 
Clutter. Rubbish. Stuff. Call it what you like, we've all got so much of it we're drowning in it. It gradually takes over our houses and our lives. All this stuff is a huge source of stress today, affecting everything from our lifestyle choices to our personal development [...] Don Aslett is a cleaning specialist. He believes that we're addicted to stuff $[\ldots]$

(English Unlimited B1+, Rea \& Clementson, 2011, p. 62)

All this is balanced by conspicuous philanthropy - texts about charities are de riguer. Neither is the hard-won veneer of gender balance which is filtering into ELT coursebooks (see, for example, Gray \& Block, 2014) familiar to all their market cultures, many of which still have strict gender-determined roles (see Ćatibušić, Gallagher, \& Karazi, 2019a and 2019b, for instance, on Syrian learners). The danger of imposing Western cultural values and priorities such as these onto users in very different cultural contexts is twofold. In some, textbook content might be espoused uncritically by its users (Tomlinson \& Masuhara, 2018). Furthermore, the values embedded in textbooks can be identified with successful learning of the language, as noted by Tajeddin and Teimournezhad (2015). Even the inclusion of 'cultural universals' - no coursebook is without its unit on family or relationships - cannot be culture-neutral, although attempts are being made in more recent books at using such topics to promote intercultural understanding, via personalisation activities and the like.

Ungrateful critics, therefore, including even some of their authors (e.g. Bell \& Gower, 1998, 2011) were not long to look 'under the skin' of the re-invented coursebook. The more international flavour and contemporary format were said to have given them a frantic 'busy-ness' and a 'magazine-like appearance' (Richards, 2014, p. 20) - reduced even to a 'tourist's perspective' according to some (Yuen, 2011, p. 459). More fundamentally, this internationalism was seen as being merely cosmetic; 'a shift towards international settings does not inevitably entail a non-Anglo-centric perspective on English and culture' (Gerday, 2015, p. 10). Accusations of cultural inappropriacy continued to be levelled against coursebooks, ranging from the practical - coursebook portrayal of consumerism and affluence, to the attitudinal - the projection of emotionality, aspiration and assertiveness as desirable attributes (Harwood, 2014, pp. 4-5) - and issues of cultural appropriacy spill over into pedagogy.

The implications of all this for the learner-user, it is claimed, are that they can find it difficult to identify with the lives they see represented in their language coursebook: 'the life reflected in the EFL [English as a foreign language] textbooks seems to be unrealistic for the students with different experiences of life', writes Ates (2012, p. 19) in the Turkish context. And while educationalists might maintain that exposure to different experiences is what learning is all about, in practice, perceived relevance is an important motivational factor for learners. In one Spanish study on the coursebook Headway Intermediate (Soars \& Soars, 2003), for instance, 62\% of participants reported feeling the coursebook content had medium or low relevance to them in terms of 'their hopes, daily life, jobs, problems, concerns, and leisure activities' (Melliti, 2013, p. 8). This can lead to disaffection; 'Presented with an English language coursebook whose content, and the values which underlay this content, are unfamiliar or even alien, many learners are straightaway disenfranchised' (Ottley, 2014, p. 12). More fundamentally, in many non-Western contexts, their users balk at culturally alien behaviour; 'foreign language textbooks are replete with various instances of foreign culture that counter the indigenous cultural values and morals' assert Shah, Ahmed, and Mahmood (2014, p. 91). Citing the findings of an evaluation of ELT textbooks used in the Malaysian context, they add 'certain patterns of behaviour in English-speaking social contexts are not desirable, being incompatible with local values' (p. 91). Neither, it seems, does sidestepping the cultural minefield through 'versioning', as in Challenges 3 (Williams et al., 2007), developed for the Middle-Eastern Market, guarantee 'relevance'. While studiously avoiding references to religion, writes one user, 'the reading texts themselves, are about distant places unknown to these learners' (Benjamin, 2015, p. 30).

The coursebook thus remains stymied by the 'cultural bind'. Publishers cannot (profitably) accommodate the diversity of their world-wide markets so continue to produce 'one size fits all' coursebooks, thus taking a calculated hit in terms of global acceptability. The upshot is that the ELT coursebook 
seems destined to walk a cultural tightrope between the diversity of cultures which it seeks, at the same time, to portray and to serve.

\subsection{WE and ELF in coursebooks}

It is ironic that a publishing empire whose profits are built on the diffusion of the English language across the globe - as a lingua franca and in the form of diverse World Englishes (WEs) - only minimally acknowledges these forms in its coursebooks. The relatively new, interrelated fields investigating and characterizing WEs, that is, the multiple varieties of geographically/politically-defined global Englishes, and English as a lingua franca (ELF), have offered us attested descriptions of the English language in all its 'kaleidoscopic plurality' (Vettorel \& Lopriore, 2013, p. 485) as used in diverse settings around the globe. Working from 2017 statistics offered by Crystal (2019), with around a billion speakers of English as an L2 and around the same number as a lingua franca, at just 388 million, first language speakers are outnumbered by L2 and ELF speakers by over five to one. This must mean that the majority of English users communicate more frequently with other L2 users than with native speakers (Vettorel \& Lopriore, 2013) and, indeed, may never come into contact with such. This geopolitical reality contrasts starkly with the predominantly Anglo-centric, native-speaking world projected in the 'global' ELT coursebook. The conclusions in study after study of contemporary ELT coursebooks are remarkably similar. Two 2013 surveys, one of ten ELT coursebooks published between 2008 and 2013 (Vettorel \& Lopriore, 2013) and another of six contemporary coursebooks (Tomlinson \& Masuhara, 2013) had similar findings with regard to opportunities to hear or learn to use ELF. Vettorel and Lopriore observed no 'significant changes [...] related to the plurality of Englishes, not to mention ELF. Characters continue to be prevalently NSs (native speakers), settings and accents overwhelmingly Inner Circle, Anglophone ones' (Vettorel \& Lopriore, 2013, p. 497), with these Inner Circle voices being predominantly British in the books surveyed by Tomlinson and Masuhara (2013). The vast majority of spoken models in the listening material provided in the three coursebooks Buckledee analysed (2010) were likewise of 'RP' (received pronunciation) or other NS Englishes, with few instances of non-native models. While the NNS (non-native speaker) presence has increased slightly in the latest generation of coursebooks, Marr and English (2019) point out that the NNS tends to be pidgeonholed as a language learner - so, by implication, not a competent English user. There is some research among English language learners to suggest that they prefer 'native-speaker' models (e.g. Timmis, 2002; Carrie \& McKenzie, 2018) by which they tend to mean models from 'Inner Circle' speakers (and a preference for British English in particular). However, this is incongruent with the sociolinguistic realities of English language use and needs of the majority of English users in the twenty-first century. The British ELT industry's focus on standard NS models might suggest that it has either a blinkered attitude to, or a reluctance to acknowledge, critical geo-political and sociolingual shifts - hence its portrayal in its coursebooks of a sort of 'fictionalised' Britain. Indeed, this might be said to be a reflection of a broader perception in (some sectors of) British society, of which Britain's 'retrenchment' and removal of itself from the European fold is the ultimate symptom.

\subsection{The fictional Britain in ELT coursebooks}

For nearly 100 years, Debrett's Handbook has advised the British public on social etiquette, that is, how to behave in social situations. The Handbook receives more than 10,000 enquiries a year [...] The most frequently asked questions have changed a lot over the years. In 1994, one of the most common questions was 'What should you do if you meet the Queen?'

(English File Intermediate, Latham-Koenig et al., 2019, p. 38).

There remains among many of its world-wide learners, a surprising but persistent view of the English language as inherently British with the accompanying accoutrements of what is perceived as 'British 
culture' and 'Britishness'; 'The language was born in England' asserted one participant in Timmis' 2002 study (2002, p. 245) while Marr (2005) quotes a student as stating 'London [...] is the home of the English language [...] it is the real English' (2005, p. 5). The corollary is that such learners still aspire to an NS model that is British; Marr and English quote one teacher as saying of their Chinese students that "many [...] are very concerned with accent and "sounding British" as a measure of success' (2019, p. 65) while another said students 'requested to be in classes taught by British teachers as this was viewed as the more desirable accent to pick up' (p. 65). Indeed, as Carrie and McKenzie point out, some language attitude research 'has [...] shown RP [...] to be the prestige variety amongst learners' (2018, p. 322). This perception could be construed, conversely, as resulting from a sort of indoctrination - a factor of the teaching material learners are exposed to (see, for example, Marr \& English, 2019, p. 86). As with the lack of opportunities to hear WEs and ELF in coursebook audio noted above, a study of sixty written texts in six coursebooks from three major British ELT publishers between 2008 and 2011 showed the 'vast majority [represented] a single variety, British English' (Clavel-Arroitia \& Fuster-Márquez, 2014, p. 130). This marks an ambivalence in the coursebooks (as Clavel-Arroitia \& Fuster-Márquez note) towards their own international aspirations; 'This strong preference [for British English] is often specified in the introductory pages although the textbooks under scrutiny have an international outlook' (2014, p. 130).

The representation of Britain in coursebooks might be seen as a way of perpetuating itself. Even the latest crop of coursebooks (as at time of writing) include material on the British Royal Family (Headway Intermediate, Soars \& Soars, 2019; English File Intermediate, Latham-Koenig et al., 2019), for example. More fundamentally, despite surface level tweaks in response to criticism in this regard, coursebooks persist in portraying Britain as a homogeneous society. In terms, first of all, of class and socio-economic status, to judge by images and texts in coursebooks, this is a society that is urban, middle-class, well-educated and aspirational, 'a world of middle-class mores and comfortable mobility [...] woke and worthy dialogues and pictures of happy, shiny people with perfect teeth' writes McCarthy (2020, p. 9), describing English File fourth edition (Oxenden, Latham-Koenig, Lambert, \& Seligson, 2020) and Empower Starter (Doff, Thaine, Puchta, Stranks, \& Lewis-Jones, 2020). This has been the particular hobby horse of one writer, John Gray; in, for example, 'All middle class now? [...] The case of ELT textbooks' (written with David Block), it is remarked that 'one feature of contemporary UK-produced textbooks for the global market is the way in which they are increasingly peopled by spectacularly successful middle-class cosmopolitans' (Gray \& Block, 2014, pp. 67-68). As worrying is their failure (or reluctance?) to represent Britain as a multi-cultural society. The preponderance of Standard British English in coursebook audio material has already been noted. This ignores, and misrepresents, the sociolinguistic reality of Britain with its numbers of 'superdiverse' cities in which English, let alone Standard British English, is not the majority language/variety. To judge by their illustrations, though, global coursebooks still portray Britain as being predominately white to international audiences. There is certainly some representation of racial diversity, but within the confines of the middle-class - circling back to McCarthy's and Gray's observations noted above.

\subsection{Admitting the 'winds of change' from SLA research?}

The strongest reservation about coursebook dominance in the language teaching field has to do with the shaky relationship between the coursebooks intended to teach the language and the research that explores this process. Unlike other fields - one would be concerned at medical practice not being based on medical research, for example - second language acquisition (SLA) research seems to march alongside ELT coursebook pedagogy, with only an intermittent 'trickle-down' influencing teaching methodologies and approaches.

Some of the significant developments in our understanding of how languages are learned over the past 50 years have included: the importance of the balance between declarative and procedural knowledge (knowledge 'about' the language versus knowledge gained from using it effectively); the theory of 'teachability', based on the learner's interlanguage being receptive to 'new' linguistic structures (hence 
'learnability'); the role that affect and cognitive engagement play in language learning; the importance of learners 'noticing' linguistic features. The overall paradigm shift in our understanding of language acquisition has been that creating conditions for 'inductive' learning (of grammar rules and so on) makes for more effective and durable learning than simply exposing learners to explicit language rules.

Yet it is difficult to trace the pedagogical interpretation of these findings as any fundamental change to coursebooks methodologies. Instead, certain elements garnered from L2 acquisition research findings are adopted and built into coursebook pedagogy in a coursebook-friendly form. A good case in point is 'consciousness-raising' ( $C-R)$, the pedagogical interpretation of an inductive approach to learning grammar and lexical forms, drawing on Schmidt's work on the importance of 'noticing' (e.g. 1990). In many of today's coursebooks, learners are typically asked to look at language samples and INFER grammar rules in controlled C-R exercises:

Look at sentences 1-7 from the article. Which modal verbs mean:

a. I'm sure about this? ... b. This is a possibility?

(English Unlimited B1+, Rea \& Clementson, 2011, p. 17)

However (as Nitta and Gardner found in their 2005 research on the use of C-R in coursebooks), these are usually immediately followed by either controlled practice (within, for example, gap-fill or matching exercises) and/or production activities - along with reference to a 'grammar check' section for learners to check their hypotheses. This sort of accelerated version of C-R undermines its theoretical rationale, which is the gradual development of procedural knowledge.

It would seem that the historically grammar-led syllabus and fast-paced, varied format and content make the ELT coursebook intrinsically unsuitable to implementing a more gradual C-R type methodology. However, a branch of applied linguistics that is itself built on inferring 'rules' of language use from language data, corpus linguistics (CL), lends itself naturally to building a C-R approach into learning materials. CL has formed the basis of a novel coursebook format and approach piloted in one coursebook series, Touchstone (McCarthy, McCurtin, \& Sandiford, 2008). Touchstone's approach takes learners more gradually and thoroughly through the inductive learning process using material based on corpus data. One of its unique features is that it offers a corpus-informed treatment of pragmatics, addressing long-standing criticism of coursebooks about their incomplete, decontextualised and even misleading presentation of dialogue (Cohen \& Ishihara, 2013; Harwood, 2014). This is partly a result of the common coursebook practice of 'economising' by combining grammar practice with pragmatics, as these two extracts illustrate:

1. Students are given the following model to check with each other if they have done a series of tasks for booking a holiday:

A. Have you booked the tickets yet?

B. No, I've already told you, I haven't done that yet.

(Language to Go, pre-intermediate, Cunningham \& Mohamed, 2002, p. 39).

2. The following example is given of how to make 'short answers' sound friendlier and more polite:

A. Did you have a good day at college?

B. No, I didn't, I didn't think the lessons were very interesting today.

(Headway Intermediate, Soars \& Soars, 2019, p. 130).

This last contrasts interestingly with this authentic spoken extract from the British National Corpus (BNC) which shows a somewhat more natural probing to get this 'longer' answer: 
Mother: Did you have a good day at school?

Son: Mhm.

Mother: Mhm. What did you do today?

Son: I did a painting.

(BNC, 2007).

There is, it seems, a long way to go before most coursebooks offer dialogues approaching pragmatic reality; most tend to go for a neat, pseudo-authenticity and staccato turn-taking. Touchstone apart, few coursebooks have braved the wilds of corpora to harvest the authentic untidiness of real speech, although some have corpus-informed lexical and grammatical aspects. Innovations (Dellar \& Walkley, 2008) claims to use a 'lexical approach' based, of course, on corpora, while books like face2face (Tims et al., 2005) and Objective First Certificate (Capel \& Sharp, 2008) use data from the Cambridge Learner Corpus, with face2face also drawing, like Touchstone, on the Cambridge International Corpus. Another positive change is that corpora now have an indirect influence on coursebooks, as they increasingly align with The Common European Framework of Reference for Languages (CEFR) levels which are based on corpus-informed lexical and grammatical specifications (Timmis, 2015, p. 128).

SLA research has, in recent years, acknowledged and explored the effect on learning of what can be broadly called 'affective' factors. They are intrinsic to that sine qua non of learning, motivation, which is so sensitive to aspects like perceived relevance, interest and appeal, confidence, unease and anxiety. Some of these would seem natural considerations for coursebook publishing (or indeed for any market); relevance and appeal are surely fundamental to successful sales and, indeed, aesthetic appeal is one of the strong selling points of ELT coursebooks. But there is a tension here with another part of the coursebook design brief. While the prohibition of 'PARSNIP' topics, mentioned earlier, guards against offending other cultures, at the same time it inhibits coursebooks from including material on subjects most of interest and relevance to the young adults who make up their majority audience. This sort of 'sanitisation' or 'neutralisation', as Gray calls it (2001), makes for 'bland', 'dry and dull' texts and materials; quite a refrain in coursebook critiques (see, for example, Timmis, Mukundan, \& Alkhaldi, 2009, p. 12; Tomlinson \& Masuhara, 2013, p. 245; Masuhara, Hann, Yi, \& Tomlinson, 2008). Tomlinson reiterates the 'unengaging blandness' (2012, p. 162) of coursebook materials in his 2012 materials development overview.

Steering clear of potentially provocative topics reduces 'affective engagement' accordingly. A research study (Freeman, 2014) into question types that invoke affect in four series of coursebooks, Headway (Soars \& Soars, 1986, 1996, 2003, 2009), Cutting Edge (Cunningham \& Moor, 1998, 2005), English File (Oxenden \& Latham-Koenig, 1999, 2006) and Inside Out (Kay \& Jones, 2000, 2009) over the years 1986 to 2009 revealed that these touched on only two of the five 'levels' of affect identified in Krathwohl, Bloom, and Masia's taxonomy (1964) of the affective domain. The question types were predominantly 'personal response' questions (elicited by the 'what do you think?' type prompts) with far fewer 'evaluation' questions (where discussion prompts are given). These question types involve only the 'lower' levels two and three, RESPONDING and VALUING, of the five levels Krathwohl et al. describe, neglecting the two highest order affective factors; CONCEPTUALISING/ORGANISING and IDENTIFYING WITH VALUES.

Likewise, safe, 'harmless' subjects (Akbari, 2008a, p. 281) only feebly stimulate the cognitive engagement that is so important to durable learning (see, for example, Craik, 2002; Tomlinson, 2012). Freeman's 2014 study also revealed a growing preference for 'explicit' questions (in which the answers can be found directly stated in the text) across all four series analysed, especially Headway, which, again referring to Bloom's taxonomy, this time to the taxonomy of the cognitive domain (revised by Anderson \& Krathwohl, 2001), call on the lowest two of the six higher order thinking skills. Furthermore, coursebooks substantially fail to stimulate creativity, the topmost thinking skill, a study of the tasks in five current coursebooks suggested (Brennan, 2019). Authentic materials have been shown to stimulate emotional and intellectual involvement (see, for example, Mishan, 2005) 
but coursebooks insist on editing away the authenticity of the original materials they select. Clavel-Arroitia and Fuster-Márquez's 2014 study of sixty written texts within six different B2/C1 level textbooks revealed that almost all (58 of the 60) had been adapted in terms of quality (lexicosyntactic rewordings) and/or length. The study describes a systematic standardising of texts, such as the substituting of idiomatic expressions/varietal variations in the original materials with standard British English expressions. This sort of reductive adaptation denies higher level students both cognitive challenge and sufficient exposure to 'real world' English.

It seems to me that the way our knowledge of SLA transfers to today's ELT coursebooks is, all told, via a process of 'Chinese whispers' whereby SLA research findings are filtered through the prisms of established pedagogical formulae and practice, emerging as a 'textbook-defined' pedagogy (Akbari, 2008b, p. 647). There are thus fundamental issues with the pedagogical approaches taken in coursebooks.

\subsection{Methodology and the coursebook}

Language teaching, in the West at least, has been under a Communicative dictatorship for the last five decades. Most teachers currently practicing have been born and bred into the approach, making it hard for them to view it critically. It has thus become the unquestioned, default pedagogy in the classroom as well as in the coursebooks used within them. Even where other teaching approaches have managed to influence coursebooks - such as corpus-informed approaches - they have tended to be moulded to the (coursebook version of) Communicativeness.

While the core principles of the Communicative approach are well known and beyond our scope here, prioritising interaction and meaningful communication, a 'critical pedagogy' take on communicative language teaching (CLT) which recognises that the tenets of any educational system reflect societal norms and values, exposes how it epitomises a worldview, attitudes and behaviours that are very Western. The 'personalisation' activities typical of communicative textbook materials, for example, promote engagement and fluency in the appropriate cultural settings. However, it must be recognised that these techniques are situated within 'a discourse of psychotherapy' (Kullman, 2013, p. 36) fed by North American traditions of psychoanalysis which uphold a 'cult' of 'emotional frankness' (Prodromou \& Mishan, 2008, p. 200) and 'reify' self-disclosure (Kullman, 2013). Such behaviours can be uncomfortable and alien to some cultures. Teachers of Syrian students in an Irish refugee programme, for example, observe their 'unease at talking about deeply personal issues', one teacher recounting 'I remember a guy said to me "in Syria we tell our problems to the wall"' (Ćatibušić, Gallagher, \& Karazi, 2019b, p. 298).

The classroom treatment of the many discussion tasks in coursebooks (the ubiquitous 'what do you think?' activities) is based on our flatter Western hierarchies. The teacher acts as 'floating' collaborator around discussion groups; this makes for a sort of 'communicational promiscuity' (Mishan \& Timmis, 2015, p. 42) which can be unfamiliar and awkward for students from cultures used to a transmission mode of teaching and/or clearly delineated teacher-learner roles. Many cultures, of course, still identify language teaching with 'learning grammar' (see, for example, Latif, 2017; Tasseron, 2017). Although ELT coursebooks evolved away from the original 'grammar-free' version of CLT in the late 1970s and 80s, on the back of feedback from ELT markets, they retain typical Communicative features which can be puzzling to learners from some backgrounds. Teachers of Syrian students in Ireland, for instance, felt that they balked at the approach; 'with TEFL teaching it's all communicative [...] and conversation and games and that kind of thing, they're not used to that, and they go in and say "they're not teaching us grammar"' (Ćatibušić et al., 2019a, p. 147). All this is aptly summed up by Marr and English; 'the soil in which [CLT] is rooted, its pedagogical inheritance, is different from many of the contexts in which it has been introduced' (2019, pp. 96-97).

All in all, methodology is the ultimate paradox of the global coursebook. However internationalised coursebooks are in terms of images and text content, these have to be clothed in an appropriate pedagogical framework to make them effective 'teaching materials'. Defaulting to (some permutation of) a 
'communicative approach' exposes the coursebook, for all its globalised trappings, as intrinsically Western, and a poor methodological fit for some of its contexts.

\section{Conclusions - and ways forward?}

This article has described the uneasy symbiosis I see as existing between the ELT publishing industry and SLA and applied linguistics research. My central argument is that the over-ambitious scope of the global coursebook causes it to 'fall between two stools'. The coursebook is the way it is (to paraphrase Singapore Wala, 2003, p. 60) because of what it tries to do. A benign view of many of the criticisms levelled here has it that 'textbook publishers do not conspire to convert textbook users to their view of the world. They simply (and inevitably) portray the world as they know it and are often unaware of the potential conflict between their views of teaching, of learning, of the target language, and of the target culture and the views of the textbook users' (Tomlinson \& Masuhara, 2018, p. 41). They are, in other words, delimited, like Cinderella's slipper - as is the central contention in this article. Nor, it seems, do they have an actual detrimental effect on language learning according to one comprehensive study; 'there are strong indications that GTs [global textbooks] can play an important role in helping, and not harming, second language learning' (Hadley, 2014, p. 230, my italics).

However, the sort of 'first do no harm' maxim hinted at in both these quotes is hardly aspirational and smacks of a certain complacency on the part of the ELT industry; ' $90 \%$ of teachers who took part in an Oxford impact study found that English File improves students' speaking skills' (English File Intermediate, Latham-Koenig et al., 2019, back cover blurb). Indeed, the global coursebook sector as a whole seems to have a sort of 'if it ain't broke don't fix it' attitude. It is remarkably resistant to the type of criticisms from the ELT and associated fields articulated in this article and 'notoriously conservative and slow to respond to calls for change from the applied linguistics community' (Gilmore, 2015, p. 516). Where publishers are more adventurous, more open to ideas from applied linguistics, is in their teacher resource books. ELT publishers Oxford University Press and Cambridge University Press both have extensive ranges of teacher resource books covering areas such as drama and improvisation, using mental imagery in L2 learning, project work and learnerbased teaching. These are approaches that rarely appear in these publishers' coursebooks, if at all. But because resource books have neither the international reach nor the commercial clout of global coursebooks, the sort of pedagogical eclecticism they offer is marginalised. For its main cash cows, the industry appears, all in all, to largely adhere to mainstream teaching approaches, taking on board influences from applied linguistics that it considers viable in pursuit of customer satisfaction and continued sales, and with this ethos has managed to maintain a booming industry.

One possible resolution to what I have argued is the global coursebook's Achilles' heel - the overwhelming diversity of its world-wide audience - is a reimagining of globalisation as 'localisation', replacing global coursebooks with versioned or regionally-produced ones. Localisation has been particularly championed by writers such as Brian Tomlinson and Rod Bolitho, who argue that this practice circumvents the central weakness of the global coursebook - local relevance. That these could be web-based local versions of coursebooks in many contexts becomes feasible with the increasing global penetration of the internet.

Indeed, the ELT publishing industry would do well to follow the lead of researchers in the area of technology and language learning, to better explore the potential of the online environment for a more suitable cultural space. Already global and multi-cultural, cyberspace is inhabited by the same international youth who are the industry's main target audience. The shared interests of this 'youth culture' include music, video, technology, sport, social media, which contemporary coursebooks have already picked up on to an extent. Moving online would thus make for an alignment of content and media, using formats and media the digital generation is familiar and comfortable with, all situated within an authentically intercultural environment. From a practical, commercial perspective, digital materials can be updated on a regular basis more easily and cheaply than can print-based ones. 
What is more, to play devil's advocate with respect to the whole coursebook 'cultural correctness' debate, going forward, it could be that as citizens of a digital and globalised world, upcoming generations of learners might be less in need of cultural 'buffering'. Online exposure to the world means they are increasingly 'street-wise', cosmopolitan and more cognisant of, and open to, diversity. In the learning environment they might appreciate being offered the challenge of the unfamiliar, which, while it might conflict with their (culturally-formed) mores, may help develop a more critical cultural worldview. Learning, after all, involves broadening horizons.

On a more fundamental level, I would hope that applied linguistics and coursebook writing could breach the 'never the twain shall meet' barrier more often, as CL has done to an extent, for example. Another sub-field of applied linguistics, materials development, has also been quite successful in acting as a bridge between the two, along with often strident critique, feeding 'usable' theory, principles and practices into coursebook writing. It would also seem important to welcome coursebook authors into the fold. Particularly in the case of global best-selling titles such as Headway, authors undoubtedly have a greater impact on language learners world-wide than applied linguists - yet they are 'effectively invisible in the academic world' (Swan, 2018, p. 252) - with the converse also being true of course.

In sum, it would seem that some resolution to the conundrum described in this article would be to cater to the international English language learning market through the production of more targeted, localised learning materials while at the same time, paradoxically perhaps, seeking to more effectively exploit the global online platform where learners (and society in general!) increasingly congregate. Feeding into this, it would be good to see closer interdisciplinary collaboration in ELT materials development (in all media), as argued by Gilmore (2015), along with greater pedagogical eclecticism. At the time of writing, the global pandemic of 2020 has catapulted online education to the fore, and demonstrated the tremendous capability of the education sector to mobilise and innovate. The time may be propitious, perhaps, to surf this wave of innovation and re-invigorate the language teaching materials sector.

\section{References}

Akbari, R. (2008a). Transforming lives: Introducing critical pedagogy into ELT classrooms. ELT Journal, 62(3), $276-283$. Akbari, R. (2008b). Postmethod discourse and practice. TESOL Quarterly, 42(4), 641-652.

Anderson, L., \& Krathwohl, D. A. (2001). A taxonomy for learning, teaching and assessing: A revision of Bloom's taxonomy of educational objectives. New York, NY: Longman.

Appel, J. (2011). Moments of practice: Teachers' knowledge and interaction in the language classroom. In J. Huttner, B. Mehlmauer-Larcher, S. Reichl, \& B. Schiftner (Eds.), Theory and practice in EFL teacher education: Bridging the gap (pp. 38-54). Bristol, UK: Multilingual Matters.

Arab, S. A., Riche, B., Ameziane, H., Khouas, N. and Louadj, K. (2005). Spotlight on English three. Algiers, Algeria: O.N.P.S. Arab, S. A. (2006). On the move. Algiers, Algeria: O.N.P.S.

Ates, M. (2012). The English textbook writing project in Turkey. Folio, 15(1), 18-21.

Bell, J., \& Gower, R. (1998). Writing course materials for the world: A great compromise. In B. Tomlinson (Ed.), Materials development in language teaching (pp. 116-129). Cambridge, UK: Cambridge University Press.

Bell, J., \& Gower, R. (2011). Writing course materials for the world: A great compromise. In B. Tomlinson (Ed.), Materialsd evelopment in language teaching (2nd edn.) (pp. 135-151). Cambridge, UK: Cambridge University Press.

Benjamin, P. (2015). Cultural appropriacy in materials adaptation: Do we need to walk on eggshells? Folio, 16(2), 30-41.

BNC Consortium. (2007). British national corpus, baby edition. Oxford Text Archive.

Bolster, A. (2014). Materials adaptation of EAP materials by experienced teachers (Part I). Folio, 16(1), 16-22.

Bolster, A. (2015). Materials adaptation of EAP materials by experienced teachers (Part II). Folio, 16(2), 16-21.

Brennan, D. (2019). Creative engagement in the English language classroom. Folio, 19(1), 22-31.

British Council. (2008). Teaching English: Course books. London: British Council.

Buckledee, S. J. (2010). Global English and ELT coursebooks. In C. Gagliardi \& A. Maley (Eds.), 2010. EIL, ELF, global English: Teaching and learning issues (pp. 141-151). Bern, Switzerland: Peter Lang.

Canagarajah, S. (1999). Resisting linguistic imperialism in language teaching. Oxford, UK: Oxford University Press.

Capel, A., \& Sharp, W. (2008). Objective first certificate. Cambridge, UK: Cambridge University Press.

Carrie, E., \& McKenzie, R. M. (2018). American or British? L2 speakers' recognition and evaluations of accent features in English. Journal of Multilingual and Multicultural Development, 39(4), 313-328.doi: 10.1080/01434632.2017.1389946 
Ćatibušić, B., Gallagher, F., \& Karazi, S. (2019a). Beyond ESOL provision: Perspectives on language, intercultural and integration support for Syrian refugees in Ireland. In F. Mishan (Ed.), ESOL provision in the UK and Ireland (pp. 133-154). Bern: Peter Lang.

Ćatibušić, B., Gallagher, F., \& Karazi, S. (2019b). An investigation of ESOL provision for adult Syrian refugees in Ireland: Voices of support providers. In F. Mishan (Ed.), ESOL provision in the UK and Ireland (pp. 287-314). Bern: Peter Lang.

Clavel-Arroitia, B., \& Fuster- Márquez, M. (2014). The authenticity of real texts in advanced English language textbooks. ELT Journal, 68(2), 124-134.

Cohen, A., \& Ishihara, N. (2013). Pragmatics. In B. Tomlinson (Ed.), Applied linguistics and materials development (pp. 113126). London, UK: Bloomsbury Academic.

Craik, F. (2002). Levels of processing: Past, present... and future. Memory, 10(5-6), 305-318.

Crystal, D. (2019). The Cambridge Encyclopedia of the English language (3rd ed.). Cambridge: Cambridge University Press. Cunningham, G., \& Mohamed, S. (2002). Language to go, pre-intermediate. London: Pearson Longman.

Cunningsworth, A. (1995). Choosing your course book. Cambridge, UK: Cambridge University Press.

Cunningham, S., \& Moor, P. (1998). Cutting edge intermediate. Harlow: Longman.

Cunningham, S., \& Moor, P. (2005). New cutting edge intermediate (2nd ed.). Harlow: Longman.

Dellar, H., \& Walkley, A. (2008). Innovations. Andover, UK: Heinle Cengage Learning.

Doff, A., Thaine, C., Puchta, H., Stranks, J., \& Lewis-Jones, P. (2020). Cambridge English empower starter. Cambridge, UK: Cambridge University Press.

Freeman, D. (2014). Reading comprehension questions: The distribution of different types in global EFL textbooks. In N. Harwood (Ed.), English language teaching textbooks: Content, consumption, production (pp. 72-110). Basingstoke: Palgrave Macmillan.

Gerday, L. (2015). Whose English does the new headway upper-intermediate global coursebook spread? Université de Liège, Belgium. Unpublished M.A. thesis.

Gilmore, A. (2015). Research into practice: The influence of discourse studies on language descriptions and task design in published ELT materials. Language Teaching, 48(4), 506-530.

Gray, J. (2001). The global coursebook in English language teaching. In D. Block (Ed.), Globalization and language teaching (pp. 151-176). London: Routledge.

Gray, J., \& Block, D. (2014). All middle class now? Evolving representations of the working class in the neoliberal era: The case of ELT textbooks. In N. Harwood (Ed.), English language teaching textbooks (pp. 45-71). London: Palgrave Macmillan.

Hadley, G. (2014). Global textbooks in local contexts: An empirical investigation of effectiveness. In N. Harwood (Ed.), English language teaching textbooks: Content, consumption, production (pp. 205-240). Pagrave Macmillan: Basingstoke.

Halliday, M. A. K. (1975). Learning how to mean: Explorations in the development of language. New York: Elsevier-North Holland.

Harwood, N. (2014). English language teaching textbooks: Content, consumption, production. Basingstoke: Palgrave Macmillan.

Hutchinson, T., \& Torres, E. (1994). The textbook as agent of change. ELT Journal, 48(4), 315-328.

Hymes, D. (1972). On communicative competence. Sociolinguistics, 269-293.

Jordan, G., \& Gray, H. (2019). We need to talk about coursebooks. ELT Journal, 73(4), 438-446.

Kachru, B. (1985). Standards, codification and sociolinguistic realism: The English language in the outer circle. In R. Quirk, H. G. Widdowson, \& Y. Cantù (Eds.), English in the world: Teaching and learning the language and literatures (pp. 11-30). Cambridge: Cambridge University Press.

Kay, S., \& Jones, V. (2000). Inside out intermediate. London: Macmillan.

Kay, S., \& Jones, V. (2009). New inside out intermediate. London: Macmillan.

Krathwohl, D. R., Bloom, B. S., \& Masia, B. B. (1964). Taxonomy of educational objectives: Handbook 2: Affective domain. New York: David McKay Company.

Kullman, J. (2013). Telling tales, changing discourses of identity in the 'Global' UK-published English Language Coursebook. In J. Gray (Ed.), Critical perspectives on language teaching materials (pp. 17-39). Basingstoke: Palgrave Macmillan.

Latham-Koenig, C., Oxenden, C., \& Lambert, J. (2019). English file intermediate students' book (4th ed.). Oxford, UK: Oxford University Press.

Latif, A. (2017). Teaching grammar using inductive and communicative materials: Exploring Egyptian EFL teachers' practices and beliefs. In H. Masuhara, B. Tomlinson, \& F. Mishan (Eds.), Practice and theory in materials development in language learning (pp. 275-289). London: Bloomsbury Academic.

Maley, A., \& Peachy, N. (2017). Integrating global issues in the creative English language classroom: With reference to United Nations sustainable development goals. London: The British Council.

Marr, T. (2005). Language and the capital: A case study of English 'language shock'among Chinese students in London. Language Awareness, 14(4), 239-253.

Marr, T., \& English, F. (2019). Rethinking TESOL in diverse global settings: The language and the teacher in a time of change. London: Bloomsbury. 
Masuhara, H., Hann, N., Yi, Y., \& Tomlinson, B. (2008). Adult EFL courses. ELT Journal, 62(3), 294-312.

Mayor, M. (2016). How a single global framework is raising standards in English. Pearson English Blog. 1 November 2016. https://www.english.com/blog/global-framework-raising-standards/

McCarthy, M. (2020). Fifty-five years and counting: A half-century of getting it half-right? Language Teaching, 1-12, doi:10.1017/S0261444820000075.

McCarthy, M., McCurtin, J., \& Sandiford, H. (2008). Touchstone. Cambridge: Cambridge University Press.

McGrath, I. (2006). Teachers' and learners' images for coursebooks: Implications for teacher development. ELT Journal 60 (2), 171-180.

McGrath, I. (2013). Teaching materials and the roles of EFL/ESL teachers. London: Bloomsbury.

McGrath, I. (2016). Materials evaluation and design for language teaching (2nd ed.). Edinburgh: Edinburgh University Press.

Meddings, L., \& Thornbury, S. (2009). Teaching unplugged: Dogme in English language teaching. Peaslake: Delta Publishing.

Melliti, M. (2013). Global content in global coursebooks: The way issues of inappropriacy, inclusivity, and connectedness are treated in Headway Intermediate. Sage Open, 3(4), 1-12.

Merazga, L. (2003). Spotlight on English one. Algiers: O.N.P.S.

Merazga, 1., Achour, K., Ameziane, H., \& Bouhaduba, F. (2004). Spotlight on English two. Algiers: O.N.P.S.

Methold, K. (2000). Yingyu [Primary English], Grade 4 and Grade 5. Beijing: McGraw-Hill Education.

Mishan, F. (2005). Designing authenticity into language learning materials. Bristol: Intellect.

Mishan, F., \& Timmis, I. (2015). Materials development for TESOL. Edinburgh: Edinburgh University Press.

Nitta, R., \& Gardner, S. (2005). Consciousness-raising and practice in ELT coursebooks. ELT Journal, 59(1), 3-13.

Nunan, D. (1998-9). Go for it! (Student books 1-4). Boston, MA: Heinle \& Heinle.

Ottley, K. (2014). Please read the text on page seven: It has nothing to do with you. Folio, 16(1), 12-15.

Oxenden, C., \& Latham-Koenig, C. (1999). English file 3. Oxford: Oxford University Press.

Oxenden, C., \& Latham-Koenig, C. (2006). New English file intermediate. Oxford: Oxford University Press.

Oxenden, C., Latham-Koenig, C., Lambert, J., \& Seligson, P. (2020). English file (4th ed.). Oxford: Oxford University Press.

Ożóg, C. (2018). An Interview with Liz and John Soars. Meet the Authors. IH Journal of Education and Development, 44. http://ihjournal.com/an-interview-with-liz-and-john-soars-

Pennycook, A. (1994). The cultural politics of English as an international language. Harlow, UK: Longman.

Phillipson, R. ((1992). Linguistic imperialism. Oxford: Oxford University Press.

Ping, Q. (2018). Ideologies in primary English textbooks in China. In X. Curdt-Christiansen \& C. Weninger (Eds.), Language, ideology and education: The politics of textbooks in language education (pp. 163-180). New York: Routledge.

Prodromou, L., \& Mishan, F. (2008). Materials used in Western Europe. In B. Tomlinson (Ed.), English language learning materials: A critical review (pp. 193-212). London: Continuum.

Rea, D., \& Clementson, T. (2011). English unlimited B1 +. Cambridge: Cambridge University Press.

Richards, J. C. (2014). The ELT textbook. In S. Garton \& K. Graves (Eds.), International perspectives on materials in ELT (pp. 19-36). London: Palgrave Macmillan.

Rix, T. (2008). Schoolbooks 1950-2000: A missing chapter in British publishing history. LOGOS: The Journal of the World Book Community, 19(4), 173-177.

Schmidt, R. (1990). The role of consciousness in second language learning. Applied Linguistics, 11(2), 129-158.

Shah, S. K., Ahmed, M., \& Mahmood, R. (2014). Representation of target culture in the ELT textbooks in Pakistan: Evaluation of 'Oxford Progressive English' for cultural relevance. Journal of Education and Practice, 5(13), 89-101.

Shawer, S. F., Gilmore, D., \& Banks-Joseph, S. R. (2008). Student cognitive and affective development in the context of classroom-level curriculum development. Journal of the Scholarship of Teaching and Learning, 8(1), 1-28.

Sheldon, L. (1988). Evaluating ELT textbooks and materials. ELT Journal, 42(4), 237-246.

Singapore Wala, D. (2003). A course book is what it is because of what it has to do. In B. Tomlinson (Ed.), Developing materials for language teaching (pp. 58-71). London: Continuum.

Soars, L., \& Soars, J. (1986). Headway intermediate. Oxford: Oxford University Press.

Soars, L., \& Soars, J. (1996). New headway intermediate. Oxford: Oxford University Press.

Soars, L., \& Soars, J. (2003). Headway intermediate (3rd ed.). Oxford: Oxford University Press.

Soars, L., \& Soars, J. (2009). Headway intermediate (4th ed.). Oxford: Oxford University Press.

Soars, J., \& Soars, L. (2019). Headway intermediate students book (5th ed.). Oxford: Oxford University Press.

Swan, M. (2018). Applied linguistics: A consumer's view. Language Teaching, 51(2), 246-261.

Tajeddin, Z., \& Teimournezhad, S. (2015). Exploring the hidden agenda in the representation of culture in international and localised ELT textbooks. The Language Learning Journal, 43(2), 180-193.

Tasseron, M. (2017). How teachers use the global ELT coursebook. In H. Masuhara, B. Tomlinson, \& F. Mishan (Eds.), Practice and theory in materials development in language learning (pp. 290-311). London: Bloomsbury Academic.

Thornbury, S. (2000). A dogma for EFL. IATEFL Issues, 153 (2), 2.

Thornbury, S. (2017). Scott Thornbury's 30 language teaching methods. Cambridge: Cambridge University Press.

Timmis, I. (2002). Native-speaker norms and International English: A classroom view. ELT Journal, 56(3), $240-249$.

Timmis, I. (2015). Corpus linguistics for ELT: Research and practice. Abingdon, UK: Routledge. 
Timmis, I., Mukundan, J., \& Alkhaldi, A. (2009). Coursebooks: Soft or fair targets? Folio, 3(2), 11-13.

Tims, C., Redstone, C., \& Cunningham, G. (2005). face2face pre-intermediate, Polish ed. Cambridge: Cambridge University Press.

Tomlinson, B. (2010). What do teachers think about EFL coursebooks? Modern English Teacher, 19(4), 5-9.

Tomlinson, B. (2012). State of the art review: Materials development for language learning and teaching. Language Teaching, $45(2), 143-179$.

Tomlinson, B., Hill, D. A., \& Masuhara, H. (2000). English for life 1. Singapore: Marshall Cavendish.

Tomlinson, B., \& Masuhara, H. (2013). Adult coursebooks. ELT Journal, 67(2), 233-249.

Tomlinson, B., \& Masuhara, H. (2018). The complete guide to the theory and practice of materials development for language learning. Oxford: Wiley \& Sons.

Vettorel, P., \& Lopriore, L. (2013). Is there ELF in ELT coursebooks? Studies in Second Language Learning and Teaching, 3(4), 483-504.

West, M. (1926). New method readers. Bombay and Calcutta, India: Longman.

Williams, M., Mugglestone, P., \& Fricker, R. (2007). Challenges 3. Middle East Edition Pearson Education Limited.

Yuen, K.-M. (2011). The representation of foreign cultures in English textbooks. ELT Journal, 65(4), 458-466.

Zheng, X., \& Zhou, Y. (2016). On foreign cultural content in English textbooks: A case study of the textbook used in Chinese junior middle schools: Go for it. Folio, 17(1), 24-32.

Freda Mishan has over 40 years' experience in TESOL. Having taught EFL in England, Italy, Israel and Ireland, she moved on to lecture in ELT on TESOL Masters and Ph.D. programmes at the University of Limerick, Ireland. Her research interests and publications are primarily in materials development, including development of intercultural language learning materials, as well as blended learning and English for speakers of other languages. Her main publications include Materials development for TESOL (co-authored with Ivor Timmis, 2015, Edinburgh University Press) and Designing authenticity into language learning materials (2005, Intellect). She has edited or co-edited a number of books (ESOL): Mishan (2019) ESOL provision in the UK and Ireland: Challenges and opportunities (Peter Lang); Masuhara, Mishan, and Tomlinson (2016) Practice and theory for materials development in L2 learning (Cambridge Scholars Publishing); and Mishan and Chambers (2010) Perspectives on language learning materials development (Peter Lang). Contributions to recent volumes on language learning and materials include chapters in Developing expertise through experience (Maley, 2019), Authenticity in materials development for language learning (Maley \& Tomlinson, 2017); Second language acquisition research and materials development for language learning (Tomlinson, 2016); The Cambridge guide to blended learning for language teaching (McCarthy, 2016); and Norton and Buchanan (forthcoming), The Routledge handbook of materials development for language teaching She is editor of the Materials Development Association (MATSDA) journal, Folio.

Cite this article: Mishan, F. (2022). The Global ELT coursebook: A case of Cinderella's slipper? Language Teaching, 55(4), 490-505. https://doi.org/10.1017/S0261444820000646 